\title{
SELECTIVE LOGGING INTENSITY ALTERS THE POPULATION STAND STRUCTURE OF CULLENIA-MESUA-PALAQUIUM DOMINATED TROPICAL WET EVERGREEN FOREST OF THE WESTERN GHATS, SOUTH INDIA
}

\author{
RAMACHANDRAN, V. S. ${ }^{1 \#}-$ MoHANDASS, D. ${ }^{2 \#}-$ CAMPBell, M. J. ${ }^{3}-$ MAMmideS, C. ${ }^{4}-$ \\ SHAO, S-C..$^{*}$ \\ ${ }^{1}$ Centre for Environmental Studies, Amrita Vishwa Vidyapeetham (University) \\ Amrita Nagar, Ettimadai, Coimbatore - 641112, Tamil Nadu, India \\ ${ }^{2}$ Ecological Field Station, Edhkwehlynawd Botanical Refuge (EBR) \\ Amaggal Forest, Doddacombai - 643 219, Nilgiris, India \\ ${ }^{3}$ Centre for Tropical Environmental and Sustainability Science (T.E.S.S.) \\ School of Marine and Tropical Biology, James Cook University, Cairns, Queensland, Australia \\ ${ }^{4}$ Guangxi Key Laboratory of Forest Ecology and Conservation, College of Forestry \\ Guangxi University, Daxuedonglu 100, Nanning 530004, P.R. China \\ ${ }^{5}$ Gardening and Horticulture Department, Xishuangbanna Tropical Botanical Garden \\ Chinese Academy of Sciences, Yunnan 666303, P.R. China \\ ${ }^{\#}$ These authors equally contributed to this paper. \\ *Corresponding author \\ e-mail: shaoshicheng@xtbg.org.cn; phone: +86-189-8819-6796 \\ (Received $12^{\text {th }}$ Jan 2019; accepted $24^{\text {th }}$ May 2019)
}

\begin{abstract}
The present study was conducted in a population structure of selectively logged tropical wet evergreen forest, Cullenia-Mesua-Palaquium (CMP) forest series in the tropical wet evergreen forests of the Nelliampathy Hills, Western Ghats. The study was aimed to focus on how selectively logged treatment influences the density and basal area of CMP forest series stand structure. We sampled the number of individual trees $(\geq 1 \mathrm{~cm} \mathrm{dbh}$, diameter at breast height $)$ of CMP at 30 sites $(20 \times 50 \mathrm{~m}$ quadrat size), covering an area of 30.8 hectare (ha) in total. A total of 5936 tree individuals sampled had a mean density of $246 \mathrm{ha}^{-1}$ and basal area of 20.73 metre square $\left(\mathrm{m}^{2}\right) \mathrm{ha}^{-1}$ from an area of 0.1 to 2.5 ha. Tree density per hectare and basal area differed significantly among plots with different logging treatments. Tree density and basal area were significantly lower in highly logged plots as compared to moderately logged and unlogged plots. The density of smaller trees was significantly higher in moderately logged plots. We suggest that heavy logging treatments might be a serious threat to the CMP forest series and may possibly alter its population structure and that the moderately logged treatments showed positive impacts on CMP stand structure and regeneration.
\end{abstract}

Keywords: basal area, disturbance, forest management, large trees, tree extraction

\section{Introduction}

Globally, more than 400 million hectares of tropical forest are in the logging estates (Blaser et al., 2011; Senior et al., 2017; Silva et al., 2018) and the world's tropical forests have been affected by intensive commercial logging for at least several decades (Johns and Skorupa, 1987; Chapman and Chapman, 1997; Gardner et al., 2009; Putz et al., 2012; Poudyal et al., 2018). Logging is a major threat in reducing the native forest 
area (Gatti et al., 2015) and potentially results in species extinction (Pimm and Raven, 2000). In addition to clear cut logging, selective logging is also an important driver of forest alteration across the tropics with $\sim 20 \%$ of all tropical forests selectively logged between 2000 and 2005 (Asner et al., 2009; Ansell et al., 2011; Magrach et al., 2016). Selective logging can negatively alter the ecological interaction of the remnant tree diversity and population structure leading to a negative impact on forest structure (Okuda et al., 2003; Yamada et al., 2013; Gatti et al., 2015). As a result of the alteration of ecological interactions in the forest due to selective logging (Schleuning et al., 2011; Magrach et al., 2016), many endemic and rare species could possibly decline at a rapid pace (Laurance et al., 1999; Zhu et al., 2004). Therefore, logging activity poses a serious threat to the long-term sustainability of the population of certain tree species in the tropical forest ecosystem.

In this study, silviculture practices is defined as the process by which the trees established in large area of forest would be removed and replaced by new tree regeneration, resulting in the production of distinctive forms of woods (Troup, 1966). It is also demarcated as "the art and science of producing and tending forests by manipulating their species establishment, species composition, structure and dynamics to fulfil the tropical forest management purposes" (ITTO, 2002). Therefore, tropical silviculture practices may play a major role in the present and future to ensure forest sustainability and sustainable production of forest products (Peña-Claros et al., 2008; Villegas et al., 2009). However, silviculture systems emphasizes the method of raising forest products by the influence of timber extraction (Ramachandran, 2008). Previous studies also demonstrates that silviculture was carried out by clearcutting (Hoffman, 1924; Isaac, 1956), partial cutting or selective logging (Kirkland and Brandstrom, 1936).

Selective logging activity may also decrease the forest area (McDonald et al., 2006) and remove the larger trees in a tropical forest (Osazuwa-Peters et al., 2015). Both forest area and the large tree presence are crucial in determining the capacity of the tropical forest to sequester carbon (Slik et al., 2013). Therefore, examination of selective logging impacts on selected tropical forests is important to determine the impact of human interventions on the population structure of plant communities. Some studies suggests that efficient management of selective logging could bring a number of trials that are related to the enhancement of forest products (Rist et al., 2012; d'Annunzio et al., 2015) and aid in preventing carbon emissions, including reduction of the available terrestrial biodiversity among tropical forests (Leadley et al., 2014; Köhl et al., 2015; Pearson et al., 2017). However, several studies also report that the real selective logging negatively impacts on forest community, which leads to forest degradation and reduction of forest products supplements (Irland, 2011; Hethcoat et al., 2018), in turn diminishing the volume of carbon stock perspective and the value of wildlife habitat (Martin et al., 2015).

In the Western Ghats of southern India, there is a number of designated series of forest types encompassing a rich endemic and endangered tree flora (Pascal, 2004; Ramesh et al., 2009). Of these, the Cullenia-Mesua-Palaquium forest series (hereafter referred to as "CMP forest") found in the mid-elevation (700-1400 m) regions of the Western Ghats is considered a unique (Pascal, 2004) and important tropical wet evergreen climax forest type (Ramesh et al., 2009). In some parts of the Western Ghats, human disturbance of CMP forests has resulted in the loss and heavy fragmentation of this forest type along with thicket formations within some human maintained savannas 
(Pascal, 2004). The current study was conducted in mid-elevation (700-1400 m) regions of the tropical wet evergreen forest of the Nelliampathy Hills, southern Western Ghats. Logging began in this region during the 1950s and continued into the 1980s in order to increase forest trees as a method of silviculture solely for timber extraction. As a result, several of the forest series including CMP forest have experienced significant disturbance and fragmentation. In this study, we examined the residual influence of previously selected logging treatments nearly 20 years after the intensive selective logging ceased. Examinations include a comparison of the recovery of stand structure and tree density of the CMP forest series, which have been logged at different intensities post-logging. Prior to this research, there was no reliable information available on the impact of logging treatments on any of the regional forest series nor the population structure of the trees in these areas of the Western Ghats. Therefore, this study is the first attempt to examine the impact of selective logging treatments on the tree population structure of CMP forest. The study addresses the following hypotheses: 1) the total density and basal area of CMP forest series would increase in response to different intensities of selective logging; 2$)$ the small $(>1 \mathrm{~cm}$ diameter at breast height (dbh) and large (> $30 \mathrm{~cm} \mathrm{dbh)} \mathrm{tree} \mathrm{density} \mathrm{and} \mathrm{basal} \mathrm{area} \mathrm{of} \mathrm{CMP} \mathrm{forest} \mathrm{series} \mathrm{would}$ increase in response to different intensities of selective logging; 3) logging treatment would have a significant influence on tree density and basal area of CMP series along with different elevational gradients.

\section{Materials and Methods}

\section{Study area}

The study was conducted in the tropical evergreen wet evergreen forest of the Nelliampathy Hills of the Western Ghats in South India (Figure 1A). The elevation ranges from 780 to $1633 \mathrm{~m}$ asl. Nelliampathy hills run south from the edge of the Palghat Gap and the junction of Anamalai and Parambikulam Hills (Figure 1A).

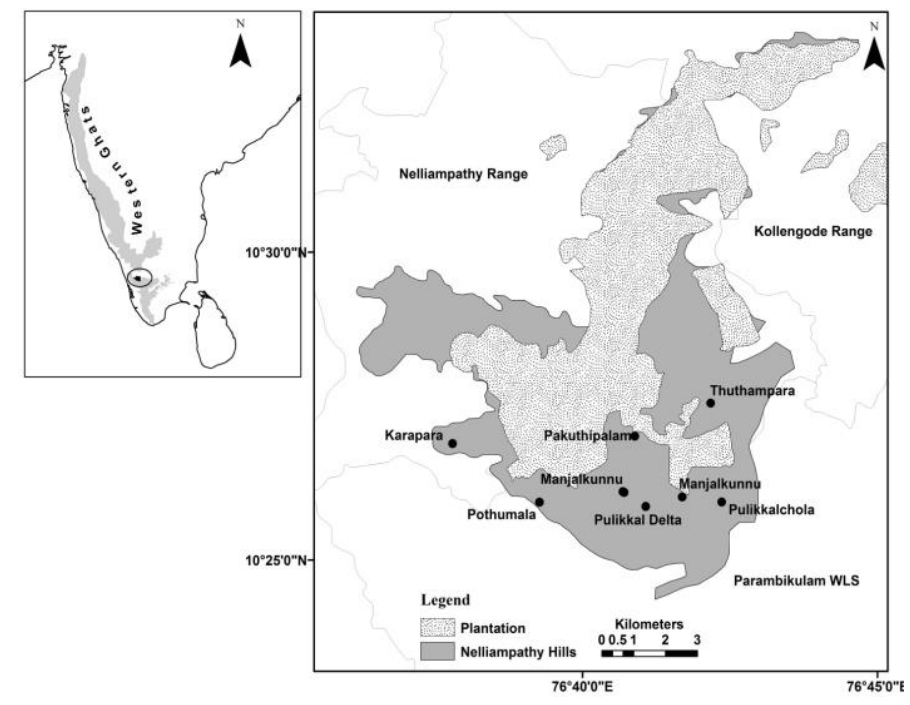

Figure 1A. Map shows that locations of the major study areas in the Nelliampathy hill ranges, namely (i) Karapara, (ii) Manjalkunnu (iii) Pakuthipalam (iv) Pothumala (v) Pulikkalchola (iv)

Thuthampara, including the 30 sampled sites (see Appendix 1) examined in the tropical evergreen forests of the Western Ghats, southern India 
The rock formation of Nelliampathy is composed of Cambrian cover and entirely reconfirmed as faults and metamorphism (Mani, 1974; Krishnan, 1974). The Pre-Cambrian crystalline rocks contain Khondalite series of Gneiss and Charnockite series of granite intrusions (Nair, 1988). The soil of the study area is generally red, sandy loam, porous with a $\mathrm{pH}$ ranging from 4.5 to 7.5 though the soil in the flat areas along the hills contain loam mixed with high levels of clay (Chandrasekaran et al., 1977). The tropical evergreen forest of the study site has been classified as medium elevation type of the Cullenia exarillata-Mesua ferrea-Palaquium ellipticum forest composition (Pascal, 1988; Ramachandran and Swarupanandan, 2013). As mentioned, large areas of these forests were selectively logged during the period 1950-1986 (Matthew, 2001); however, areas of old-growth unlogged forests still exist.

The study was carried out in the Pulikkalchola forests located at $10^{\circ} 47^{\prime} \mathrm{N}$ and $76^{\circ} 70^{\prime} \mathrm{E}$. The climate is humid with the mean annual rainfall of the study area over a 10-year period from 1995-2004 of $2457 \mathrm{~mm}$. Rainfall in this region is characterized as monsoonal peaks from June to August while a distinct dry season runs from December to March. The minimal and maximal rainfall reported from 1994-2004 was 626-2028 $\mathrm{mm}$ and 1441-4278 $\mathrm{mm}$, respectively. The number of rainy days varied from 127-144 $\mathrm{a}^{-1}$. The annual average temperature of the study area ranged from $5^{\circ} \mathrm{C}$ to $30^{\circ} \mathrm{C}$ (Ramachandran and Swarupanandan, 2013, 2018). During the comparatively dry period of December to March, the mean monthly temperatures ranged $20.4-25.2^{\circ} \mathrm{C}$ (Ramachandran and Swarupanandan, 2013; IMD, 2018). Rainfall increased $>79 \%$ in study areas during the year 2018 (IMD, 2018).

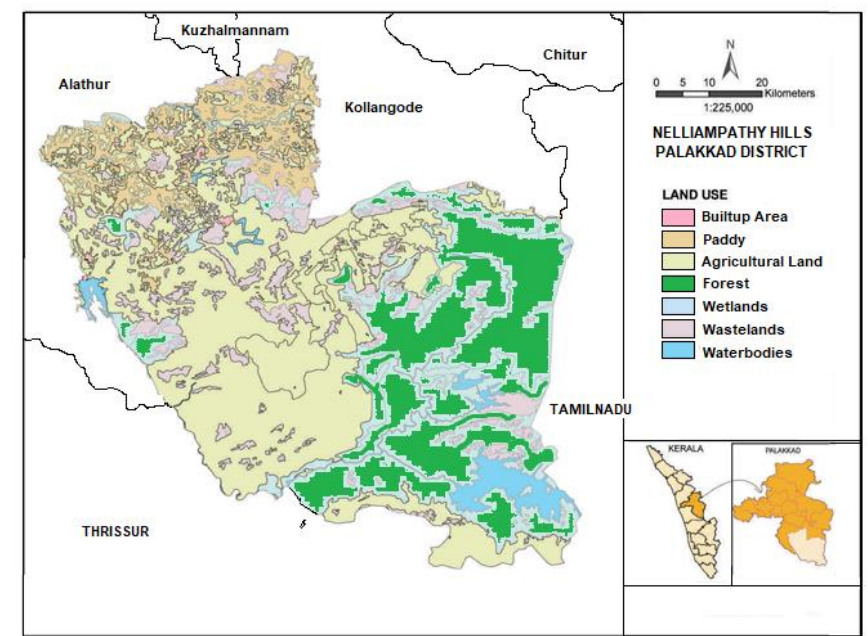

Figure 1B. Map showing that land use changes which displayed the builtup area, paddy field, agricultural land, forest area, wetland, wastelands and waterbodies in the of Nelliampathi Hills, Palakkad district of the Western Ghats, India

The dominant vegetation series of the study region are Cullenia exillarita A. Robyns (Malvaceae), Mesua ferrea L. (Calophyllaceae) and Palaquium ellipticum (Dalzell) Baill. (Sapotaceae). These species are tall trees with heights ranging between 30 and $40 \mathrm{~m}$ and are commonly located in the interior of the continuous forest patches of the tropical wet evergreen forests of the Nelliampathy Hills. The trees generally do not branch out until they reach a certain height (approximately $10 \mathrm{~m}$ ). The dominant tree 
species in Cullenia-Mesua-Palaquium (CMP) forest series is of a unique structure at a particular elevation ranging 550-700 m altitude in the Western Ghats (Pascal, 2004). The forests produce large fleshy fruits which serve as useful food resources for the resident birds and mammals. Moreover, the area is the primary habitat for the endangered lion-tailed macaque (Pascal, 1988; Ganesh and Davidar, 1999). These forest series species are an important resource for wild animals despite the fact that they display a narrow geographical distribution in the Western Ghats.

\section{Description of selective logging treatments}

Selective logging was considered only as a silvicultural system implemented in the natural forests of Kerala (FAO, 1984, 1985; Chundamannil, 1993). It started as early as 1885 (Nair, 1988). In the study area, a part of the growing stock in the form of mature trees was removed during the 1950s, 1960s, 1970s and 1980s, encompassing a large area each year, either at the same time or at an interval of 15-30 years (Baur, 1964; FAO, 1989; Lamprecht, 1993). This selective logging system practiced in India is actually a Quasi-Selection System or Selection Felling (Troup, 1916; Seth, 1960) or the Selective Felling/Logging (Lal, 1961; Srivastava, 1983). In the early 1950s, forest administration used a method of treatment for the vast extent of the forest using a limitedly trained staff with poor silvicultural knowledge. They chose selective felling as the only method available to make use of the stock of mature and over-mature trees of marketable species (Troup, 1916, 1921). In this method, mature trees of selected species with a minimum girth limit (> $30 \mathrm{~cm}$ to $80 \mathrm{~cm}$ girth) were logged under a definite felling cycle, leaving only the seed bearers where natural regeneration is deficient. In India, this is the most widely practiced system applicable to the evergreen, moist deciduous and dry deciduous forests (FAO, 1989). Selective logging was applied and aimed to increase the regeneration of species by improving the light conditions of the forest floor (Stracey, 1959; FAO, 1984; Kadambi, 1986). In the studied plots, selective logging was implemented to extract CMP species suitable for railway sleepers, ship masts and electric poles (Nair, 1961; FAO, 1989).

In the present study, selective logging treatments were categorized into high, moderate and unlogged treatments. The plots are defined where the trees were selectively extracted and removed to serve as timber during 1950-1985. We categorized the treatment of selective logging based on the removal of a number of trees per hectare as: (1) High-logging: where the CMP trees were removed based on fixed minimum diameter limit that varied from $30-60 \mathrm{~cm}$ dbh with a felling cycle of $15-30$ years. The area studied included the number of trees that were removed from an area of 10-20 ha-1 and the minimum distance between two trees marked for felling fixed at $20 \mathrm{~m}$. (2) Moderate-logging: The technique was similar to high-logging, however, the trees were removed from 2-6 ha- ${ }^{-1}$ area keeping the same distance of $20 \mathrm{~m}$ between the tree removed. (3) Unlogged: No logging work was undertaken over a century. The above information was collected from forest department records.

\section{Field sampling}

During the year 2004-2006, we surveyed and sampled the tree population of CMP species using quadrat methods. We laid randomly $20 \times 50 \mathrm{~m}$ quadrats and subdivided the plot into $10 \times 10 \mathrm{~m}$ subplots for sampling in 30 sites (Appendix 1). The total 
sampled area was 30.8 ha. All the individuals encountered with a minimum dbh of $\geq 1 \mathrm{~cm}$ (diameter at breast height) were measured at $1.3 \mathrm{~m}$ from above ground level (Dallmeier et al., 1992), excluding the buttresses. All individuals were marked and numbered sequentially using aluminum tags (Ramachandran and Swarupanandan, 2013). Species specimen was collected, identified and deposited in the herbarium of Kerala Botanical Herbarium Center.

\section{Data analysis}

All individuals of the studied CMP species were counted from sample plots. They were converted into per hectare and later log-transformed for data analysis. The basal area of each individual was calculated using the formula $(\mathrm{DBH})^{2} \times \pi / 4$ (Mohandass and Davidar, 2009) and then converted into log-transformed among logging treatments. The mean and standard error of tree numbers and basal area of CMP was compared among logging treatments (such as high, moderate and unlogged). We categorized trees with a $\mathrm{dbh}$ of $<50 \mathrm{~cm}$ as smaller trees and the trees with a dbh of $>50 \mathrm{~cm}$ as larger trees (Persha and Blomley, 2009). The mean tree density and basal area of smaller stem dbh class $(\leq 49.9 \mathrm{~cm} \mathrm{dbh})$ and larger stem dbh class $(\geq 50 \mathrm{~cm} \mathrm{dbh})$ were calculated and logtransformed for analysis to compare among logging treatments. Analysis of variance (ANOVA) was used to test for differences in the mean number of tree individuals and basal area of CMP among logging treatments. We also used ANOVA to test for differences in the mean number of smaller trees and larger trees among logging treatments. F-statistic is the ratio of one-way ANOVA where $\mathrm{F}=$ variation between vegetation parameter means / variation within the vegetation parameters. Number of treatments $(\mathrm{N})$ and degree of freedom (DF) were included in F-statistics. The P-value is the probability of given statistical model where the null hypothesis is true and the values greater than or equal to the actual observed values are indicated as significant differences (Wasserstein et al., 2016).

We used the Tukey's pairwise comparison to check for significant differences in tree density and basal area of CMP between and within the logging treatments (high, moderate and unlogged). Repeated measures of ANOVA was used to test the effect of post-logging recovery of CMP tree density and the basal area between high and moderate logging as compared to unlogged sites. We estimated mean value of postlogging age class of CMP tree density and basal area that included smaller and larger tree density and the basal area of CMP among different logging treatments. In addition, we also tested CMP forest recovery in order to compare the mean value of tree density and basal area of those vegetation parameters by ANOVA. Analysis of covariance (ANCOVA) was used to test the effect of logging treatment on tree density and basal area. All statistical analysis was performed using the software MedCalc. (version 12.2.1.0).

\section{Results}

A total of 5936 tree individuals with density ranging 17.3 to 1250 per hectare and average basal area of $20.73 \mathrm{~m}^{2} \mathrm{ha}^{-1}(\geq 1 \mathrm{~cm}$ dbh) were recorded from various logged treatments for the three species that were under study - Cullenia exallirata, Mesua ferrea and Palaquium ellipticum. The tree individuals ranging from 19-155 were enumerated in highly logged plots, 200-697 from moderately logged plots and 83-334 stems from unlogged plots. The basal area of the studied species ranged from 1.3-19.5 
$\mathrm{m}^{2} \mathrm{ha}^{-1}$ in highly logged plots, $13.3-79.4 \mathrm{~m}^{2} \mathrm{ha}^{-1}$ in moderately logged plots and $6.9-56.1 \mathrm{~m}^{2} \mathrm{ha}^{-1}$ in unlogged plots.

\section{Treatment of logging on CMP tree density}

In highly logged plots, the mean number of trees accounted for $111.8 \pm 13.89$ (std. error), while it was $402.58 \pm 67.2$ and $180.12 \pm 30.62$ in moderately and unlogged plots. It shows that the density of CMP series differed significantly (ANOVA $\mathrm{F}_{3,29}=12.69, \mathrm{P}=0.0001$ ) among different logging treatments. Moreover, Tukey's HSD comparison shows that mean tree density was significantly higher in moderately logged plots compared to high (Tukey's HSD $=6.88, \mathrm{P}=0.0002$ ) and unlogged plots (Tukey's $\mathrm{HSD}=4.11, \mathrm{P}=0.019)$. However, no significant difference was found in the mean density of trees between high and unlogged plots (Tukey's HSD $=2.76, \mathrm{P}=0.1431$; Figure 2a).

\section{Treatment of logging on CMP basal area}

The mean basal area of trees in highly logged plots was $10.94 \pm 1.5\left(\mathrm{~m}^{2} \mathrm{ha}^{-1}\right.$; std. error), $39.92 \pm 8.91\left(\mathrm{~m}^{2} \mathrm{ha}^{-1}\right)$ in moderately logged plots and $22.3 \pm 5.5\left(\mathrm{~m}^{2} \mathrm{ha}^{-1}\right)$ in unlogged plots. The basal area of three tree species differed significantly (ANOVA $\mathrm{F}_{3,29}=8.36, \mathrm{P}=0.0012$ ) among various sites with different logging treatments. Mean basal area of moderately logged plots was significantly higher (Tukey's HSD $=5.42$, $\mathrm{P}=0.002$ ). In contrast, there was no significant difference found between moderately logged and unlogged plots (Tukey's HSD $=2.42, \mathrm{P}=0.22$ ) or between highly logged and unlogged plots (Tukey's HSD $=3.0, \mathrm{P}=0.104$; Figure $2 b$ ).

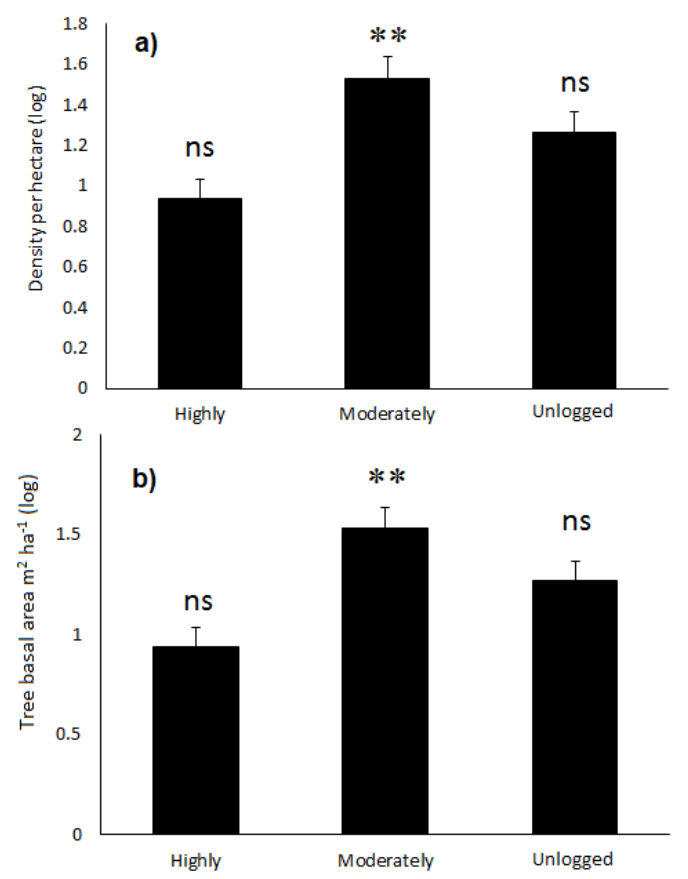

Figure 2. Treatments of different logging on (a) CMP mean tree density and (b) mean basal area $\left(\mathrm{m}^{2} \mathrm{ha}\right)$ of the tropical mid-elevation wet evergreen forests of the Nelliampathy Hills,

Western Ghats, southern India (Significant level: $* * p<0.001 ; n s=$ not significant) 


\section{Treatment of logging on smaller and larger tree density and basal area}

The density of smaller trees $(\leq 49.9 \mathrm{~cm} \mathrm{dbh})$ and larger trees $(\geq 50 \mathrm{~cm} \mathrm{dbh})$ differed significantly among different logging treatments (Small trees: $F_{3,29}=29.87, P=0.0001$; Large trees: $\left.F_{3,29}=3.22, P=0.05\right)$. Density of smaller trees was significantly higher in moderately and unlogged plots compared to highly logged plots (Figure 3a). Similarly, the density of larger trees was significantly higher in moderately logged plots than the highly logged plots $\left(\mathrm{F}_{3,29}=8.13, \mathrm{P}=0.002\right)$. However, no significant difference was found between moderate and unlogged plots (Tukey $\mathrm{HSD}=2.63, \mathrm{P}=0.169$; Figure $3 b$ ).

Similarly, the basal area of smaller and larger trees also differed significantly $\left(\mathrm{F}_{3,29}=17.2, \mathrm{P}=0.0001 ; \mathrm{F}_{3,29}=7.192, \mathrm{P}=0.003\right.$, respectively $)$ among various logging treatments. Basal area of smaller trees were significantly higher in moderately logged plots than the highly logged and unlogged plots (Tukey's HSD $=7.88, \mathrm{P}=0.0001$; Tukey's HSD $=6.79, \mathrm{P}=0.0003$ ); however, there was no significant difference found between highly logged and unlogged plots (Tukey's HSD =1.09, $\mathrm{P}=0.724$; Figure 3c). For large trees, the basal area was significantly higher in moderately logged plots (Tukey's HSD $=4.9, \mathrm{P}=0.005$ ) than the highly logged and unlogged plots. Similarly, there was no significant difference found between highly logged and unlogged plots (Tukey's HSD = 3.137, $\mathrm{P}=0.08$; Figure 3d).
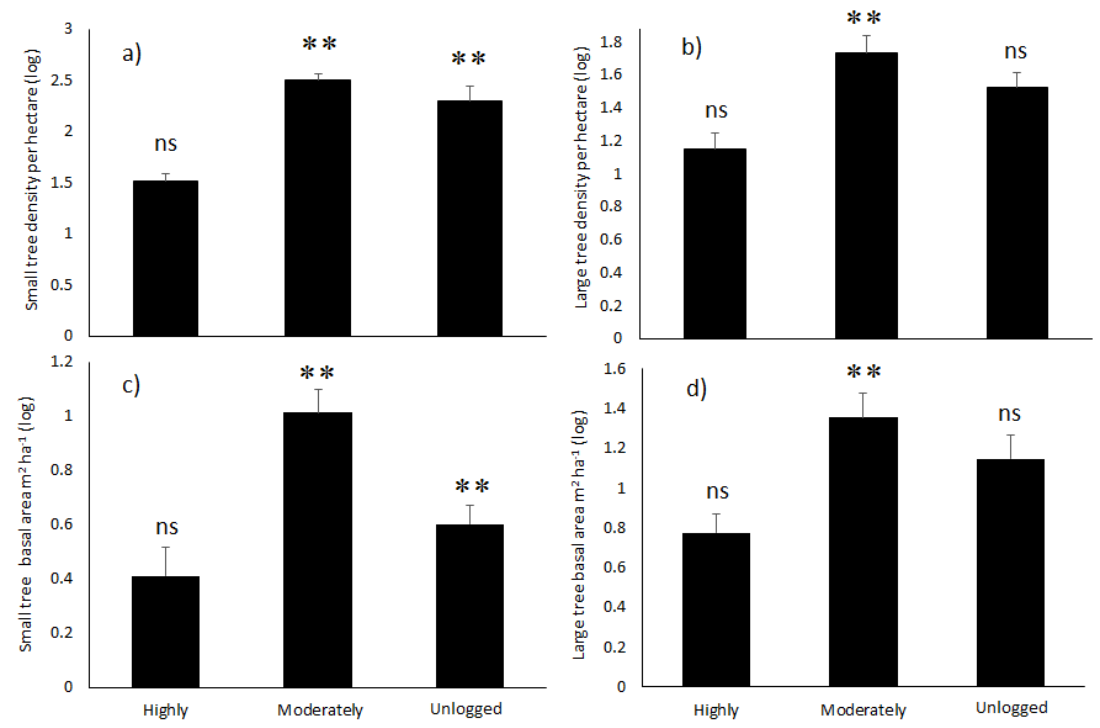

Figure 3. Treatment of logging on CMP smaller and larger tree density and basal area (log transformed) in the tropical mid-elevation wet evergreen forests of the Nelliampathy hills,

Western Ghats, southern India (a) small mean tree density and (b) large tree density in response to different logging treatments $(c)$ small mean tree basal area and $(d)$ large mean basal area in response to different logging treatments (Significant level: $* * p<0.001 ; n s=n o t$ significant)

\section{CMP recovery after logging years}

Tree density and basal area differed significantly among various sites due to logging treatment influencing $\mathrm{CMP}$ recovery $(\mathrm{F}=4.01, \mathrm{P}=0.001$ and $\mathrm{F}=5.1, \mathrm{P}=0.002),($ Table 1). All recovery periods (15-24, 25-34 and 35-45 after logging years) from highly logged sites influenced lower stem density and basal area compared to moderately 
logged sites (Table 2). Small and large tree density and basal area of highly logged sites were lower than that of the moderately logged sites, indicating that the moderately logged sites may have influenced the high number of trees as compared to highly logged sites through CMP forest series recovery by the effect of selective logging (Table 2).

Table 1. Repeated measures of ANOVA was used to test post-logging recovery and interacting between and within the variable factors of stem density and basal area of highly logged and moderately logged plots compared to unlogged sites in the CMP forest series of the Western Ghats, southern India

\begin{tabular}{c|c|c|c|c|c}
\hline Source of variation & Sum of squares & df & Mean squares & F-ratio & P-value \\
\hline Tree density & 379909.6 & 4 & 94977.4 & 4.4 & 0.008 \\
Residual & 539508.0 & 25 & 21580.3 & & \\
Tree density $\times$ Post-logging effects & 103544.6 & 8 & 12943.1 & 4.01 & 0.001 \\
Residual & 161457.1 & 50 & 3229.1 & & \\
Basal area & 5388.9 & 4 & 1347.2 & 4.6 & 0.006 \\
Residual & 7321.4 & 25 & 292.9 & & \\
Basal area $\times$ Post-logging effects & 1541.6 & 8 & 192.8 & 5.1 & 0.001 \\
Residual & 1887.6 & 50 & 37.8 & & \\
\hline
\end{tabular}

Table 2. Post-logging on all tree density $\left(\mathrm{ha}^{-1}\right)$ and basal area $\left(\mathrm{m}^{2} \mathrm{ha}^{-1}\right)$ of CMP series, smaller stem density, larger stem density and basal area of CMP series along logging treatment in the Western Ghats, southern India

\begin{tabular}{|c|c|c|c|c|}
\hline & \multicolumn{2}{|c|}{ Density ha-1 $^{-1}$} & \multicolumn{2}{|c|}{ Basal area $\mathbf{m}^{2} \mathbf{h a}^{-1}$} \\
\hline $\begin{array}{c}\text { Post-logging } \\
\text { years }\end{array}$ & Highly & Moderate & Highly & Moderate \\
\hline $18-24$ & $107.5 \pm 49.5$ & $438.5 \pm 122.5$ & $12.98 \pm 4.22$ & $43.27 \pm 17.24$ \\
\hline $25-34$ & $118.1 \pm 16.90$ & $253.5 \pm 13.71$ & $11.67 \pm 1.80$ & $27.01 \pm 13.71$ \\
\hline \multirow[t]{2}{*}{$35-45$} & $93.67 \pm 37.56$ & $478 \pm 122.34$ & $7.17 \pm 3.87$ & $46.28 \pm 17.71$ \\
\hline & \multicolumn{2}{|c|}{ Smaller tree density ha ha $^{-1}$} & \multicolumn{2}{|c|}{ Smaller tree basal area $\mathrm{m}^{2} \mathrm{ha}^{-1}$} \\
\hline $\begin{array}{c}\text { Post-logging } \\
\text { years }\end{array}$ & Highly & Moderate & Highly & Moderate \\
\hline $18-24$ & $86 \pm 44$ & $367 \pm 89$ & $3.7 \pm 1.2$ & $16.1 \pm 4.1$ \\
\hline $25-34$ & $98.7 \pm 14.42$ & $215.5 \pm 37.5$ & $3.51 \pm 0.52$ & $5.5 \pm 0.2$ \\
\hline \multirow[t]{2}{*}{$35-45$} & $81 \pm 32.56$ & $401.67 \pm 93.74$ & $2.27 \pm 0.921$ & $12.43 \pm 2.44$ \\
\hline & \multicolumn{2}{|c|}{ Larger tree density ha ha $^{-1}$} & \multicolumn{2}{|c|}{ Larger tree basal area $\mathrm{m}^{2} \mathrm{ha}^{-1}$} \\
\hline $\begin{array}{c}\text { Post-logging } \\
\text { years }\end{array}$ & Highly & Moderate & Highly & Moderate \\
\hline $18-24$ & $21.5 \pm 5.5$ & $71.5 \pm 33.5$ & $9.25 \pm 3.05$ & $27.15 \pm 13.15$ \\
\hline $25-34$ & $19.4 \pm 3.45$ & $38 \pm 16$ & $8.16 \pm 1.39$ & $21.5 \pm 13.5$ \\
\hline $35-45$ & $12.67 \pm 7.75$ & $76.33 \pm 28.60$ & $4.9 \pm 3.066$ & $33.83 \pm 15.42$ \\
\hline
\end{tabular}

\section{Discussion}

Our results suggest that moderate logging treatment increased the tree density and basal area of Cullenia exillarita, Mesua ferrea and Palaquium ellipticum, causing a positive impact on the population structure of these forest layers type in the midelevation evergreen forests of the Western Ghats. Besides, the study also showed that the tree density and basal area varied significantly, suggesting that the moderate logging influenced a higher number of smaller and larger trees. The basal area in the moderately logged plots was also higher than that of unlogged and highly logged plots. The total basal area of trees from the highly logged plots was found to be significantly lower than 
that of the moderately logged plots and unlogged plots. Post-logging recovery influenced stem density and basal area of CMP trees compared to unlogged sites; however, there was no significant difference found between highly logged and moderately logged plots during the post-logging periods. In addition, we found that the treatment of logging significantly affected the tree density and basal area with an increase in the altitude of $750 \mathrm{~m}$ to $1250 \mathrm{~m}$. Therefore, the treatment of logging changed the population structure of Cullenia-Mesua-Palaquium forest series significantly in the mid-elevation evergreen forests of the Western Ghats.

\section{Logging treatment on tree density of CMP forest series}

Previous studies showed logging to be a kind of disturbance that impacts tree diversity, species composition and forest structure (Ferry et al., 2002; Lima et al., 2002; Rutten et al., 2015; Katovai et al., 2016). According to our results, high logging sites showed a considerably low density of CMP species, due to the formation of more gaps which resulted in reduced tree regeneration. The increased light levels in the forest understorey after highly selective logging may result in sudden occurrence of many herbaceous and woody pioneer species (Woods, 1989; Nykvist, 1996; Pinard et al., 1996, 2000; Cochrane and Schultze, 1999; Fredericksen and Mostacedo, 2000; Ferry et al., 2002). This may inhibit the growth of CMP forest species regeneration and would cause a decline in the density and basal area of CMP species in the highly logged sites.

In the tropical forests of the Western Ghats, shade tolerance is an important factor which supports tree regeneration (Mohandass et al., 2016). Generally, in tropical forests, large forest trees provide more shade which would facilitate tree regeneration. Due to logging of large trees, if the shade is not sparse it may inhibit the regeneration of CMP species. Moreover, high logging pressure also resulted in increased human intervention, particularly in the highly logged plots, which disrupted tree regeneration (Rivett et al., 2016) and eventually resulted in a low number of small trees and large trees of CMP species. Therefore, it has been observed that high logging treatment may cause negative impacts on CMP series of tree recruitment and regeneration. This would be one of the major factors in changing the population structure of CMP canopy forest layer in the studied forest sites. The moderate treatment of logging influences relatively a low number of trees that are cut and results in maintaining a high number of CMP tree individuals. This results in a significantly high number of CMP trees as compared to high logging. Moreover, moderate logging treatment provided sufficient shade and light due to gap formation that facilitated a high number of tree recruitment and regeneration. Furthermore, our results showed that the small tree size numbers $(\leq 50 \mathrm{~cm} \mathrm{dbh})$ increased significantly due to moderate logging. For some unknown reasons, the large trees were not harvested in some of the moderately logged plots in the study area (Ramachandran, 2008). Moderately logged plots had a large number of trees than the unlogged plots. Eventually, the large number of trees were higher as compared to unlogged plots; however, no significant difference was found on large trees $(\geq 50 \mathrm{~cm}$ dbh) between highly logged and unlogged plots. In the highly logged and unlogged plots, large trees were not regularly removed and perhaps this might be the reason for not showing any significant differences. Though unlogged treatment showed a significantly high number in the density of smaller trees of CMP as compared to highly logged plots, there was no significant difference in the density of CMP trees between moderately logged and unlogged plots. It suggests that unlogged plots had regular tree recruitment and regeneration with less intensive disturbance by human logging, which 
could have influenced a neutral response in regeneration of small trees and a tendency to maintain large trees.

\section{Logging treatment on a basal area of CMP forest layer}

Estimating the basal area of CMP forest layer could be an important measure on forest stand structure of CMP forest layer among logged treatment plots. In the highly logged plots, basal area of CMP trees was consistently lower as compared to moderate and unlogged plots. Due to high logging treatments, smaller and large trees are lesser in number as they are harvested constantly leading to the low value of the basal area, affecting the CMP layer of forest structure. Human activity of high logging affects smaller trees as well as larger trees in numbers that may reduce the rate of tree size. Similar to density, the basal area also showed a significantly negative impact on the CMP forest layer due to high logging treatment in the studied sites. However, CMP forest layer showed significantly higher value in the basal area due to a high number of smaller trees and larger trees between moderately logged and unlogged plots. Interestingly, large tree density did not show a significant difference between the different logging methods, whereas the basal area of moderately logged plots showed a significant difference compared to high and unlogged plots. This shows that the moderately logged plots maintained large tree growth structure. Moreover, smaller trees basal area was significantly low in unlogged plots compared to moderately logged plots and the unlogged plots had a high number of large trees compared to moderately logged plots. In terms of basal area, large numbers of small trees are accumulated in moderately logged plots that exhibit a basal area significantly higher compared to highly logged and unlogged plots and shows a positive response to CMP forest layer by moderate logging treatment. Therefore, the differences in smaller and larger tree density and basal area of CMP forest layer between forest sites strongly depend on logging treatments (Bonnell et al., 2011) in the studied regions.

\section{Post-logging recovery on tree density and the basal area along logging treatments}

Several studies demonstrated that post-logging recovery and age influence species composition, density, basal area or biomass of tropical forests (Ferry et al., 2002; McDonald et al., 2008; Osazuwa-Peters et al., 2015; Darrigo et al., 2016; Arevalo et al., 2016; Katovai et al., 2016). We found that post-logging recovery on CMP tree density and the basal area was significantly higher in logged sites as compared to unlogged sites. This indicates that the logging treatments exhibit a positive response on CMP forest series in the studied sites. However, the study suggests that the moderately logged treatment type would be more effective for the regeneration and maintenance of the CMP tree densities. Removal of more trees (10-20 year per hectare) would be less effective for regeneration of CMP forest trees. Our results showed that tree numbers and basal area of moderately logged plots were higher than the highly logged sites. In addition, it was also observed that 25-35 and 35-45 post-logging recovery showed a significant difference in stem density and basal area. These indicate that the recovery of high tree density could be slow regeneration processes in the studied forests.

\section{Logging treatment on tree density and the basal area along elevation gradients}

It has been shown by our study that at all elevation gradients, the logging treatments significantly changed the population structure of CMP forest layer in the studied plots. 
High logging activity tend to alter the forest structure of CMP series by removing the best mature stems in all elevation gradients. Obviously, tree species require high light incidence at the seedling stage for survival and growth (Kleinschroth et al., 2013). Canopy opening might be increased for seedling recruitment through consistent amount of light availability. These seedlings may be that of a large amount of herbaceous and pioneer species that may inhibit the growth or regeneration of CMP species in all elevation gradients. Direct light intensity may influence a significant amount of temperature which may decline seedling recruitment of CMP species in all logged plots and elevations. Therefore, logging affects all elevation gradients and possibly influences similar consequences on tree density and basal area of CMP forest series. Therefore, enrichment planting should be considered in heavily degraded or logged areas (Kleinschroth et al., 2013) along the gradients.

\section{Conclusion}

Our results support that the logging treatments produces a significant impact on the population structure of Cullenia-Mesua-Palaquium forest series in the studied plots. Our study concludes that the moderately logged treatment resulted in a significant increase in the number of small and large trees. Highly logged plots showed a significant decline in the number of small trees as compared to moderately logged and unlogged plots. These support the fact that the heavy logging method might be a serious threat to the population structure of Cullenia-Mesua-Palaquium forest series. Moreover, C. exallilata and P. ellipticum are endemic species. Hence, it is very important to preserve this population in the mid-elevation layer of the Western Ghats. It is imperative to avoid heavy logging treatment to facilitate regeneration and to create dense population structure of the CMP forest series. The Forestry management strategy to understand how selective logging supports natural regeneration of CMP forest series due to canopy openness is crucial. Therefore future research is required to examine the natural regeneration process to understand fully the seedling dynamics of CMP forest series. In addition, further experimental study needs to be undertaken to understand the impact of logging treatment on habitat species - specifically in relation to endemism and climate change.

Acknowledgements. We are grateful to K. Swarupanandan, Forest Ecology and Biodiversity Conservation Division, Kerala Forest Research Institute, for his inordinate support during field work and thesis submission. We thank the two anonymous reviewers whose comments have greatly improved this manuscript. We thank Ms. Nisha Gopalakrishnan who helped us edit the manuscript. We are grateful to the Ministry of Environment and Forests, Government of India for the financial support, which made this study possible. Dr. J.K. Sharma and Dr. K.V. Sankaran, the former Directors of the Kerala Forest Research Institute are acknowledged for rendering the institutional facilities. We are thankful to Kerala Plantation Development Corporation for providing rainfall data; Mr. K. Sunil Kumar, Mr. Balu and Mr. Devendran for assisting us during the field study. The first author would like to thank Dr. Abhayamrita Chaitanya, Pro-Chancellor, AVVU, for providing an opportunity to work at his institutional facilities and for his support. 


\section{REFERENCES}

[1] Arevalo, B., Valladarez, J., Muschamp, S., Kay, E., Finkral, A., Roopsind, A., Putz, F. E. (2016): Effects of reduced-impact selective logging on palm regeneration in Belize. Forest Ecology and Management 369: 155-160.

[2] Balasubramanyan, K. (1987): Impact of selection felling in a forest ecosystem in Kerala. - KFRI Research Report no. S3. Kerala Forest Research Institute, Thrissur, Kerala, India.

[3] Baur, G. N. (1964): The ecological basis of rain forest management. - Forestry Commission of New South Wales, Sydney, Australia.

[4] Bonnell, T. R., Reyna-Hurtado, R., Chapman, C. A. (2011): Post-logging recovery time is longer than expected in an East African tropical forest. - Forest Ecology and Management 261: 855-864.

[5] Chandrasekharan, K. P., Muhammed Moosa, M., Ananthasubramonian, A. S. (1977): The first working plan for the Nemmara Forest Division: 1969-70 to 1983-84. - Government of Kerala, Trivandrum, $96 \mathrm{pp}$.

[6] Chandrashekara, U. M. (1991): Studies on the gap phase dynamics of a humid tropical forest. - Ph. D. Thesis. Jawaharlal Nehru University, New Delhi, India.

[7] Chapman, C. A., Chapman, L. J. (1997): Forest regeneration in logged and unlogged forests of Kibale National Park, Uganda. - Biotropica 29: 396-412.

[8] Chundamannil, M. (1993): History of forest management in Kerala. KFRI Research Report No.89. - Kerala Forest Research Institute, Thrissur, Kerala, India.

[9] d'Annunzio, R., Sandker, M., Finegold, Y., Min, Z. (2015): Projecting global forest area towards 2030. - Forest Ecology and Management 352: 124-133.

[10] Dallmeier, F., Kabel, M., Rice, R. (1992): Methods for long-term biodiversity inventory plots in protected tropical forests. - In: Dallmeier, F. (ed.) Long-term monitoring of biological diversity in tropical forest areas: Methods for establishment and inventory of permanent plots. MAB Digest 11. UNESCO, Paris.

[11] Darrigo, M. R., Venticinque, E. M., Santos, F. A. M (2016): Effects of reduced impact logging on the forest regeneration in the central Amazonia. - Forest Ecology and Management 360: 52-59.

[12] FAO. (1984): Intensive multiple-use forest management systems in Kerala (India). - FAO forestry Paper 53. FAO of UN, Rome.

[13] FAO. (1985): Intensive multiple-use forest management systems in the tropics. - FAO forestry Paper 55. FAO of UN, Rome.

[14] FAO. (1989): Review of forest management systems of Tropical Asia. - FAO forestry paper 89. FAO of UN, Rome, 228 pp.

[15] Ganesh, T., Davidar, P. (1999): Fruit Biomass and Relative Abundance of Frugivores in a Rain Forest of Southern Western Ghats, India. - Journal of Tropical Ecology 15: 399413.

[16] Gardner, T. A., Barlow, J., Chazdon, R., Ewers, R. M., Harvey, C. A., Peres, C. A., Sodhi, N. S. (2009): Prospects for tropical forest biodiversity in a human-modified world. - Ecology Letters 12: 561-582.

[17] Gatti, R. C., Castaldi, S., Lindsell, J. A., Coomes, D. A., Marchetti, M., Maesano, M., Paola, A. D., Paprella, F., Valentini, R. (2015): The impact of selective logging and clear cutting on forest structure, tree diversity and above-ground biomass of African tropical forests. - Ecological Research 30: 119-132.

[18] Hethcoat, M. G., Edwards, D. P., Carreiras, J. M. B., Bryant, R. G., França, F. M., Quegan, S. (2018): A machine learning approach to map tropical selective logging. Remote Sensing of Environment: https://doi.org/10.1101/451856.

[19] IMD. (2018): Report: Rainfall over kerala during monsoon season - 2018 and forecast for next 5 days. - Earth System Science Organization, Government of India.

[20] Irland, L. C. (2011): Timber productivity research gaps for extensive forest management. - Small-scale Forestry 10: 389-400. 
[21] Johns, A. D., Skorupa, J. P. (1987): Responses of rainforest primates to habitat disturbance: A review. - International Journal of Primatology 8: 157-191.

[22] Kadambi, K. (1986): Methods of increasing growth and obtaining regeneration of tropical rainforest. - In: Haig, I. T., Huberman, M. A., Din, V. A. (eds.) Tropical Silviculture. Vol. 2, FAO Forest and Forest Product Studies No.13, Periodical Experts Book Agency, Delhi. Pages: 67-78.

[23] Katovai, E., Sirikolo, M., Srinivasan, U., Edwards, W., Laurance, W. F. (2016): Factors influencing tree diversity and compositional change across logged forests in the Solomon Islands. - Forest Ecology and Management 372: 53-63.

[24] Kleinschroth, F., Schöning, C., Kungu, J. B., Kowarik, I., Cierjacks, A. (2013): Regeneration of the East African timber tree Ocotea usambarensis in relation to historical logging. - Forest Ecology and Management 291: 396-403.

[25] Köhl, M., Lasco, R., Cifuentes, M., Jonsson, Ö., Korhonen, K. T., Mundhenk, P., de Jesus Navar, J., Stinson, G. (2015): Changes in forest production, biomass and carbon: Results from the 2015 UN FAO Global Forest Resource Assessment. - Forest Ecology and Management 352: 21-34.

[26] Krishnan, M. S. (1974): Geology. - In: Mani, M. S. (ed.) Ecology and biogeography in India. Dr.W.B. Junk, b.v.Publishers, the Hague, 773 pp. Pages: 60-98.

[27] Lal, A. B. (1961): Silvicultural systems and forest management. - Jugal Kishore and Co., Dehra Dun, India.

[28] Lamprecht, H. (1993): Silviculture in the tropical natural forests. - In: Pancel, L. (ed.) Tropical forestry hand book. Vol.1, Springer-Verlag, New York. Pages: 728-810.

[29] Leadley, P. W., Krug, C. B., Alkemade, R., Pereira, H. M., Sumaila, U. R., Walpole, M., Marques, A., Newbold, T., Teh, L. S. L., van Kolck, J., Bellard, C., JanuchowskiHartley, S. R., Mumby, P. J. (2014): Progress towards the Aichi Biodiversity Targets: An Assessment of Biodiversity Trends, Policy Scenarios and Key Actions. - Secretariat of the Convention on Biological Diversity, Montreal, Canada. viewed 20/09/2017, $<$ https://www.cbd.int/doc/publications/cbd-ts-78-en.pdf.

[30] Lima, A. P., de Lima, O. P., Magnusson, W. E., Higuchi, N., Reis, F. Q. (2002): Regneration of five commercially-valuable tree species after experimental logging in an Amazonian forest. - R. Árvore, Viçosa-MG 26: 567-571.

[31] Mani, M. S. (1974): Physical features. - In: Mani, M. S. (ed.) Ecology and biogeography in India. Dr.W.B. Junk, b.v. Publishers, The Netherlands. Pages: 11-59.

[32] Martin, P. A., Newton, A. C., Pfeifer, M., Khoo, M., Bullock, J. M., (2015): Impacts of tropical selective logging on carbon storage and tree species richness: a meta-analysis. Forest Ecology and Management 356: 224-233.

[33] McDonald, R. I., Motzkin, G., Bank, M., Kittredge, D. B., Burk, J., Foster. D. (2006): Forest harvesting and land-use conversion over two decades in Massachusetts. - Forest Ecology and Management 227: 31-41.

[34] Mohandass, D., Davidar, P. (2009): Floristic structure and diversity of a tropical montane evergreen forest (shola) of the Nilgiri Mountains, southern India. - Tropical Ecology 50: 219-229.

[35] Mohandass, D., Chhabra, T., Pannu, R. S., Beng, K. C. (2016): Recruitment of saplings in active tea plantations of the Nilgiri Mountains: Implications for restoration ecology. Tropical Ecology 57: 101-118.

[36] Nair, S. S. C. (1998): Long-term conservation potential of natural forests in the Southern Western Ghats of Kerala. - MAB Report, Dept. of Environment, Government of India, $324 \mathrm{pp}$.

[37] Okuda, T., Suzuki, M., Adachi, N., Quah, E. S., Hussein, N. A., Manokaran, N. (2003): Effect of selective logging on canopy and stand structure and tree species composition in a lowland dipterocarp forest in peninsular Malaysia. - Forest Ecology and Management 175: 297-320. 
[38] Osazuwa-Peters, O. L., Chapman, C. A., Zanne, A. E. (2015): Selective logging: does the imprint remain on tree structure and composition after 45 years? - Conservation Physiology 3: doi:10.1093/conphys/cov012.

[39] Pascal, J. P. (1988): Wet evergreen forests of the Western Ghats of India: ecology, structure, floristic composition and succession. - Institut Francais de Pondichery, India.

[40] Pascal, J. P., Ramesh, B. R., De Francheschi, D. (2004): Wet evergreen forest types of the southern Western Ghats, India. - Tropical Ecology 45: 281-292.

[41] Pearson, T. R., Brown, S., Murray, L., Sidman, G. (2017): Greenhouse gas emissions from tropical forest degradation: an underestimated source. - Carbon Balance Management 12: 1-11.

[42] Persha, L., Blomley, T. (2009): Management decentralization and montane forest conditions in Tanzania. - Conservation Biology 23(6): 1485-1496.

[43] Pimm, S. L., Raven, P. (2000): Biodiversity extinction by numbers. - Nature 403: 843845.

[44] Poudyal, B. H., Maraseni, T., Cockfield, G. (2018): Evolutionary dynamics of selective logging in the tropics: A systematic review of impact studies and their effectiveness in sustainable forest management. - Forest Ecology and Management 430: 166-175.

[45] Putz, F. E., Zuidema, P. A., Synnott, T., Pena-claros, M., Pinard, M. A., Sheil, D., Vanclay, J. K., Sist, P., Gourlet-Fleury, S., Griscom, B., Palmer, J., Zagt, R. (2012): Sustaining conservation values in selectively logged tropical forests: the attained and the attainable. - Conservation Letters 5: 296-303.

[46] Ramachandran, V. S., Swarupanadan, K. (2013): Structure and floristic composition of old growth (unlogged) wet evergreen forests of Nelliampathy hills, southern Western Ghats. - Journal of Forestry Research 24: 37-46.

[47] Ramachandran, V. S., Swarupanandan, K. (2018): Ecological status of Palaquium ravii, an Endangered Endemic Tree, in the Nelliampathy Hills of the Western Ghats, India. The Indian Forester 144: 164-168.

[48] Ramesh, B. R., Swaminath, M. H., Patil, S., Aravajy, S., Elouard, C. (2009): Assessment and Conservation of Forest Biodiversity in the Western Ghats of Karnataka, India. Assessment of Tree Biodiversity, Logging Impact and General Discussion. Institut Francais de Pondichery. p 65-121.

[49] Rivett, S. L., Bicknell, J. E., Davies, Z. (2016): Effect of reduced-impact logging on seedling recruitment in a Neotropical forest. - Forest Ecology and Management 367: 7179.

[50] Rutten, G., Ensslin, A., Hemp, A., Fischer, M. (2015): Forest structure and composition of previously selectively logged and non-logged montane forests at Mt. Kilimanjaro. Forest Ecology and Management 337: 61-66.

[51] Senior, R. A., Hill, J. K., Benedick, S., Edwards, D. P. (2017): Tropical forests are thermally buffered despite intensive selective logging. - Global Change Biology: 12671278.

[52] Seth, S. K. (1960): Soils of the tropical moist evergreen forests of India. - Proceedings of Tropical Moist Evergreen Forest Symposium, Forest Research Institute, DehraDun, India.

[53] Silk, J. W. F., Veryburg, R. W., Kebler, P. J. A. (2002): Effects of fire and selective logging on the tree species composition of lowland dipterocarp forest in East Kalimantan, Indonesia. - Biodiversity and Conservation 11: 85-98.

[54] Silva, P. H., Gomide, L. R., Figueiredo, E. O., Carvalho, L. M. T., Ferraz Filho, A. C. (2018): Optimal selective logging regime and log landing location models: a case study in the Amazon forest. - Acta Amazonica 48: 18-27.

[55] Srivastava, T. N. (1983): A bridged glossary of technical terms. - FRI and Colleges, Dehra Dun, India.

[56] Stracey, P. D. (1959): The silviculture and management of tropical rain forest in India. Indian Forester 85: 385-409. 
[57] Troup, R. S. (1916): A note on some European silvicultural systems, with suggestions for improvements in Indian forest management. - Superintendent of printing, Calcutta, India.

[58] Wasserstein, R. L., Lazar, N. A. (2016): The ASA's Statement on p-Values: Context, Process, and Purpose. - The American Statiscian 70: 129-133.

[59] Yamada, T., Hosaka, T., Okuda, T., Kassim, A. R. (2013): Effects of 50 years of selective logging on demography of trees in a Malaysian lowland forest. - Forest Ecology and Management 310: 531-538. 


\section{APPENDIX}

Appendix 1. Site code, sampled area (ha), number of total trees, basal area $\left(m^{2} h a^{-1}\right)$, number of smaller trees and basal area $\left(\mathrm{m}^{2} \mathrm{ha} \mathrm{a}^{-1}\right)$, number of larger trees and basal area $\left(\mathrm{m}^{2} \mathrm{ha}^{-1}\right)$ and logging treatment of the tropical mid-elevation wet evergreen forests of the Western Ghats, southern India

\begin{tabular}{|c|c|c|c|c|c|c|c|c|c|}
\hline Site Code & $\begin{array}{l}\text { Altitude } \\
\text { (m) }\end{array}$ & $\begin{array}{l}\text { Sampled } \\
\text { area (ha) }\end{array}$ & $\begin{array}{c}\text { Number of } \\
\text { trees }\end{array}$ & $\begin{array}{c}\text { Basal area } \\
\mathrm{m}^{2} \mathrm{ha}^{-1}\end{array}$ & $\begin{array}{c}\text { Number of } \\
\text { smaller } \\
\text { trees }\end{array}$ & $\begin{array}{c}\text { Basal area } \\
\text { of smaller } \\
\text { trees }\end{array}$ & $\begin{array}{l}\text { Number of } \\
\text { larger trees }\end{array}$ & $\begin{array}{c}\text { Basal area } \\
\text { of large } \\
\text { trees }\end{array}$ & $\begin{array}{l}\text { Logging } \\
\text { treatments }\end{array}$ \\
\hline SLKP1 & $950-980$ & 2.3 & 697 & 79.36 & 570 & 16.1 & 127 & 63.2 & Moderately \\
\hline SLKP2 & 950 & 1.1 & 19 & 1.30 & 16 & 0.5 & 3 & 0.8 & Highly \\
\hline SLMK1ha & 780 & 1 & 27 & 1.45 & 25 & 0.2 & 2 & 1.3 & Highly \\
\hline SLMKD1 & $780-950$ & 0.6 & 190 & 14.88 & 168 & 5.9 & 22 & 9.0 & Highly \\
\hline SLMKD2 & $850-900$ & 0.3 & 81 & 6.74 & 73 & 3.1 & 8 & 3.6 & Highly \\
\hline SLMKInd & $850-900$ & 0.6 & 173 & 16.65 & 145 & 4.7 & 28 & 11.9 & Highly \\
\hline SLMKIV & $780-800$ & 0.6 & 138 & 14.47 & 110 & 3.6 & 28 & 10.9 & Highly \\
\hline SLMKIX & $750-760$ & 1 & 307 & 40.72 & 253 & 5.7 & 54 & 35.0 & Moderately \\
\hline SLMKIX1ha & 780 & 1 & 150 & 19.49 & 116 & 5.2 & 34 & 14.3 & Highly \\
\hline SLMKVII & 780 & 0.2 & 45 & 7.66 & 30 & 2.0 & 15 & 5.7 & Highly \\
\hline SLMKXIV & $780-920$ & 1 & 200 & 13.30 & 178 & 5.3 & 22 & 8.0 & Moderately \\
\hline SLPC & $750-800$ & 2.3 & 274 & 18.75 & 246 & 7.8 & 28 & 11.0 & Moderately \\
\hline SLPC1ha & 780 & 2 & 124 & 5.75 & 117 & 2.7 & 7 & 3.0 & Highly \\
\hline SLPD1 & $750-800$ & 2.3 & 463 & 40.74 & 389 & 13.4 & 74 & 27.3 & Moderately \\
\hline SLPD2 & 780 & 0.6 & 128 & 10.21 & 111 & 4.1 & 17 & 6.1 & Highly \\
\hline SLPD3 & $760-780$ & 0.5 & 155 & 17.06 & 120 & 3.5 & 35 & 13.6 & Highly \\
\hline SLPM05ha & 1095 & 0.5 & 117 & 14.22 & 95 & 3.5 & 22 & 10.7 & Highly \\
\hline SLPO & 1096-1250 & 0.5 & 157 & 17.20 & 130 & 4.9 & 27 & 12.3 & Highly \\
\hline SLPP & 780-1050 & 2.5 & 561 & 60.51 & 456 & 20.2 & 105 & 40.3 & Moderately \\
\hline SLTP & $750-800$ & 2.4 & 316 & 26.03 & 278 & 12.0 & 38 & 14.0 & Moderately \\
\hline SLTP05ha & 800 & 0.5 & 58 & 8.75 & 42 & 2.5 & 16 & 6.2 & Highly \\
\hline SLTPJK1ha & 800 & 1 & 115 & 8.34 & 104 & 2.9 & 11 & 5.4 & Highly \\
\hline ULKPA1ha & 1150 & 1 & 116 & 10.07 & 98 & 2.7 & 18 & 7.4 & Unlogged \\
\hline ULKPB1ha & 1250 & 1 & 83 & 21.27 & 47 & 2.4 & 36 & 18.9 & Unlogged \\
\hline ULMK & 950-1050 & 0.5 & 217 & 31.39 & 164 & 4.3 & 53 & 27.1 & Unlogged \\
\hline ULMM & 850 & 0.6 & 262 & 21.06 & 226 & 5.0 & 36 & 16.1 & Unlogged \\
\hline ULPC & 780 & 0.8 & 188 & 16.77 & 156 & 4.5 & 32 & 12.3 & Unlogged \\
\hline ULPC1ha & 780 & 1 & 116 & 6.86 & 103 & 3.1 & 13 & 3.7 & Unlogged \\
\hline ULPM & 1050-1150 & 1 & 334 & 56.09 & 238 & 10.0 & 96 & 46.1 & Unlogged \\
\hline ULPM05ha & 1100 & 0.1 & 125 & 14.76 & 96 & 3.5 & 29.00 & 11.3 & Unlogged \\
\hline
\end{tabular}

